\title{
Forest Management, Conflict and Social-Ecological Systems in a Changing World
}

\author{
Juan F. Fernández-Manjarrés $1, * \mathbb{C}$, Josephine MacHunter ${ }^{2} \mathbb{C}$ and Miguel A. Zavala ${ }^{3,4} \mathbb{C}$ \\ 1 Ecologie Systématique Evolution, CNRS, AgroParisTech, Université Paris-Saclay, 91405 Orsay, France \\ 2 Arthur Rylah Institute for Environmental Research, Department of Environment, \\ Heidelberg, VIC 3084, Australia; josephine.machunter@delwp.vic.gov.au \\ 3 Grupo de Ecología y Restauración Forestal (FORECO), Departamento de Ciencias de la Vida, \\ Universidad de Alcalá, Alcalá de Henares, 28805 Madrid, Spain; ma.zavala@uah.es \\ 4 Instituto Franklin, Universidad de Alcalá, Calle Trinidad 1, 28801 Alcalá de Henares, Spain \\ * Correspondence: juan.fernandez@universite-paris-saclay.fr
}

check for

updates

Citation: Fernández-Manjarrés, J.F.; MacHunter, J.; Zavala, M.A. Forest Management, Conflict and Social-Ecological Systems in a Changing World. Forests 2021, 12, 1459. https://doi.org/10.3390/ f12111459

Received: 28 September 2021

Accepted: 22 October 2021

Published: 26 October 2021

Publisher's Note: MDPI stays neutral with regard to jurisdictional claims in published maps and institutional affiliations.

Copyright: (c) 2021 by the authors. Licensee MDPI, Basel, Switzerland. This article is an open access article distributed under the terms and conditions of the Creative Commons Attribution (CC BY) license (https:// creativecommons.org/licenses/by/ $4.0 /)$.

\section{Introduction}

Conflicts are ubiquitous in forest management because of several overlapping temporal and spatial issues (see examples in tropical and temperate areas [1-5]). First, the long temporal cycles of forests make decision making particularly difficult, as decisions made today can have impacts for centuries to come [6]. Second, the large spatial scales inherent to forest ecosystems imply both a large number of ecosystem-specific management plans, but also a wide variety of actors. Finally, because of the long cycles, management plans (or the lack of them) are inherited often from previous generations, and new actors may not agree with the decisions taken before.

Forests are, par excellence, multifunctional ecosystems. By multifunctional, we mean that forests either currently provide or have the potential to provide multiple benefits or ecosystem services for society $[7,8]$. However, this multifunctionality comes at a cost because forests that occur as social-ecological systems (SESs, also known as coupled human or natural systems, or CHANS) can rarely be optimized to simultaneously achieve all desirable outcomes, necessitating trade-offs whose acceptance differs among interest groups [9]. Multifunctionality is a concept that has made it to management programs and public policies in most parts of the world. For instance, in many countries of Europe, it has been explicitly included in the legislation regarding public and private forests since the mid-1950s [10,11] and it is a current management framework in countries such as India [12] and Brazil [13], to cite just a couple. Behind this concept, what is really at stake are notions of shared landscape. As such, conflicts related to multifunctionality are frequently related to land-sparing or land-sharing approaches, a debate that is far from being closed [14]. The multifunctionality paradigm competes today with new ideas, such as rewilding [15], which, in turn, can accentuate lingering conflicts if not properly handled [16].

If conflicts are ubiquitous, as we state above, inferring general tendencies may be an important advancement towards a forest SES theory development. The question that follows then is if forest SESs would have particular types of conflicts not found in other ecosystems. Another particularity of forests is that, even if they occur on private lands, they may be under the control or strict supervision of governments in most countries of the world. The same applies to forests occurring in first nation or indigenous reserves, in which, despite the autonomy granted, the management should be in accord with national regulations. Here, our main premise would be that forest SESs would be prone to conflict due to lagged responses between the time that decisions are made by local actors and changes in the ecological and social systems, which do not necessarily follow the same cycles of decision making of local institutions, regional forest authorities, and national governments. These lags in decision making are further confounded by different views of 
the individual actors and regional administrations that understand governance differently. In this editorial article, we present first a general typology of sources of conflicts before introducing the contributions by the authors on different topics, and we conclude by raising awareness of the effects that current "transition" approaches may have for forest management considered as SESs.

\section{A Simplified Typology}

To assist with exploration of the origin of the tensions, we propose a simple twodimension typology that integrates a number of the conflicts observed in forest SESs (Figure 1).

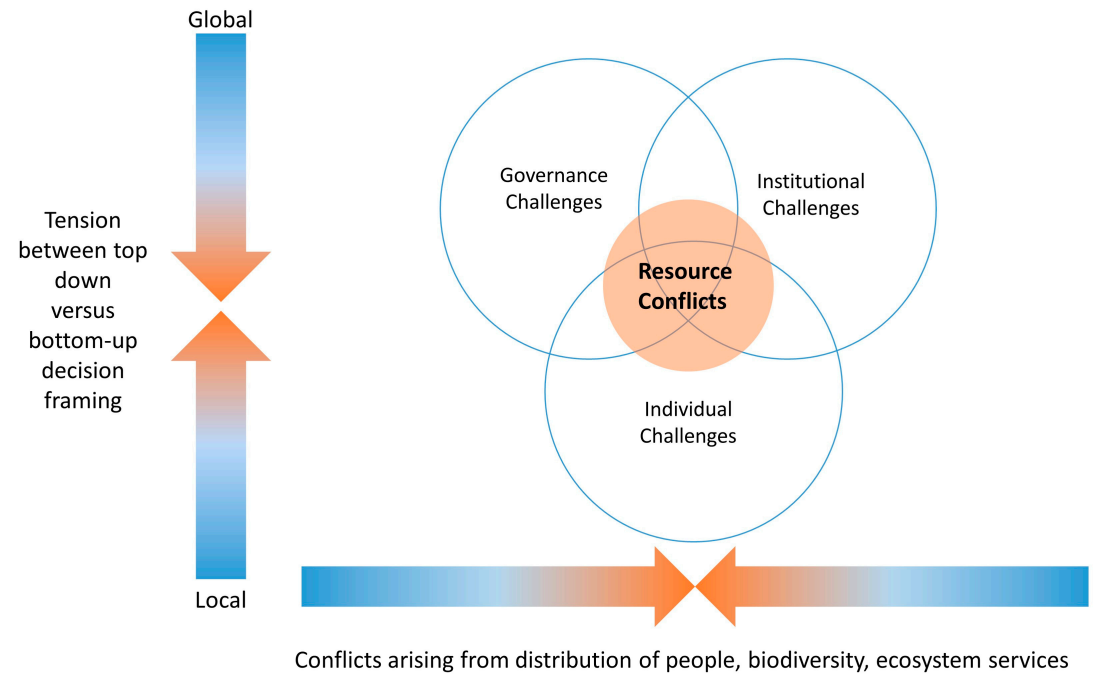

Figure 1. A simplified typology of some of the possible sources of conflicts in forests. The vertical axis represents the newly created pressures of international agreements that impact directly standing forests, afforestation, and reforestation programs. The horizontal axis represents the conflicts caused by the distribution of people (including property rights), the structure and composition of forests, and the different ecosystem services people are expecting to find. At the cross-roads of these vertical and horizontal dimensions, challenges arising from institutional factors, disputes in governance, and individual cognitive biases can collide, creating different conflicts at different scales. Transition policies (i.e., increased use of wood biomass for heating) often occur in a top-down fashion from national commitments and international agreements. Local knowledge would be related to the individual challenges regarding what management options are acceptable or not.

In many instances, conflicts arise not because of unwillingness of the parts, but because of inherent problems in the process of decision making (circle intersections in Figure 1). Institutional challenges include issues with data where researchers, managers, and decision makers facing multiple sources of uncertainty (for a review, see [17]), which are often overlooked in the decision making process [18]. Often, the decision frame is poorly articulated or may neglect key concerns of the actors involved, resulting in governance issues arising from mismatched expectations about what a desirable outcome looks like over relevant spatial and temporal scales. The overarching values to be achieved through candidate management interventions may be poorly articulated or lack discrete, measurable objectives to facilitate the evaluation of options. Often, the management options themselves may reflect status quo traps (or other individual biases) rather than genuine exploration of novel approaches that may better support attainment of desirable outcomes $[19,20]$. In the next section, we discuss how contributions fit in the typology, and at what level decision making is contributing to solving, or else perpetuating, the different described situations. 


\section{Some Issues Raised by the Contributions to the Special Issue}

\subsection{Conflicts Arising from Climate Adaptation and Mitigation Programs}

Tackling the effects of climate change on SES and preventing further climate change is a policy and management target that will arguably remain for decades to come. In the case of forests, early approaches focused on the role of forest ecosystems as stabilizers of local and regional climates, and, of course, as carbon sinks. For instance, recent findings point out that fast-growing secondary forest in the Amazon basin is more efficient as a carbon sink compared to old growth forests in the region [21]. On the other hand, quantifying whether old growth forests are carbon neutral or sinks is a subject of an ongoing debate $[22,23]$ of far-reaching consequences. As countries continue to engage in carbon emission/sequestration targets, local management will be impacted by policies that have a top-down origin, not only from a national level, but from an international level too, often labeled as "transitions" [24].

In a way, this category of conflicts exhibits most, if not all, of the dimensions depicted in Figure 1, as top-down policies collide with local expectations of actors, which themselves have other unresolved issues regarding access to markets, unfair competition, or simply rights to use the forest resource itself.

In this Special Issue, Royer-Tardiff and colleagues [25] present a portfolio approach for implementing forest zonings, in which zones that are more conserved and those that are more impacted can have different climate change adaptation roles. For the latter, the authors propose that, in heavily impacted areas where restoration is unlikely, new afforestation strategies could be tested without entering into competition with areas less exposed to climate change and that can serve as biodiversity reservoirs. The example in Canadian boreal forests that they provide of functional zoning aims at distributing in the landscape conflicting land uses, an approach that would be akin to a mixed land-sparing/land-sharing strategy. Akita and Ohe [26], in this issue, propose the use of carbon credits to avoid the lack of management in former production forests in Japan that have become nonprofitable if commercialized as timber. In this case, carbon credits act as an innovation tool and can act as way of avoiding land use conflicts, as funds for management can be sourced through this alternative. Another contribution to this journal issue (Fouqueray and colleagues) also considers the roles of carbon credits within concertation by different actors around biodiversity and production issues.

Fouqueray and colleagues [27] analyze an ongoing strategy in French forests that provides subsidies for management programs seeking to increase carbon sequestration. As this strategy can be interpreted as promoting homogeneous, low diversity, low quality managed forests, the analyzed programs have a social-ecological approach, in which consensus is sought with local partners to avoid conflicts before the programs are deployed. Additionally, in France, Sansilvestri and colleagues [28] show in high detail how topdown European policies of energetic transition model the use of wood biomass following structures inherited from fossil fuel economies that are not in accord with the way actors are organized around the forest resources.

On the other hand, conflicts in tropical countries regarding adaptation and mitigation issues may be more difficult to solve. Alusiola and colleagues, in this issue [29], analyze through the lens of political ecology how conflicts have arisen in reducing emissions from deforestation and forest degradation in developing countries (REDD+) programs in selected case studies located in East Africa (Ethiopia, Uganda, Tanzania), Southeast Asia (Indonesia, Vietnam), and Central America (Panama). The good intentions of these initiatives are smeared by unexpected side effects that include increased injustices and restrictions over forest resources, and the aggravation of historic land tenure conflicts, among others. Restrictions over forest access are one of the issues that we depict in the horizontal axis of the typology in Figure 1, as they are influenced not only by the spatial distribution of property in the forests, but by interactions of actors that may try to impose conflicting governance approaches. 


\subsection{Protected Areas and Biodiversity}

Conflicting goals between biodiversity and forestry activities are one of the more common issues worldwide. In this issue, Shneider and colleagues [30] use archival research coupled with stakeholder interviews to gain insights into a recurring problem of land preservation and forestry zones in the Czech Republic. In this case, they analyzed the perception of the local society that considers that the declaration of protected areas is a very restrictive instrument. In this study, the process started as a top-down measure from the central government that could not reach consensus with local stakeholders, leading to an abandonment of the project. Interestingly, the results refuted or did not confirm most of the arguments of stakeholders against the declaration of the protected area, showing how a lack of communication can feed unwarranted bias of the public, a situation we depict on the intersection of circles representing personal, governance, and institutional issues in Figure 1. This study is also an example of the horizontal issues that we address in the typology, as the spatial distribution of biodiversity is a "horizontal" dimension highly impacted by property rights and/or governance over forests that require zoning to define protection and extraction areas.

\subsection{Loss of Local Knowledge}

In the literature, calls for more holistic management approaches are increasing [31]. Holistic management seeks to avoid conceptual and practical oppositions in terms of private/public lands, conservation/exploitation, and academic knowledge/local knowledge. Among these, local knowledge and local indigenous knowledge consideration appear to be a way of avoiding conflicts and resolving opposing positions. In this issue, Branca and colleagues [32] reconstruct through interviews the historical-cultural and social cohesion function that the forest plays in a rural community in the Mediterranean island of Sardinia. Rural population abandonment, with the concomitant loss of local knowledge, was identified as the main risk facing the management of coppiced forests. New propositions of shorter rotation times sparked a debate that hit the national press in Italy, labeling the plan as the destruction of a millennium-old forest mostly by an urban public not familiar with traditional coppice methods. The example by Branca and colleagues adds to an ever-growing body of research demonstrating that concertation and incorporation of local knowledge is a condition for sustainable management of forests, for both tropical and temperate countries [33]. Local knowledge would be represented in our typology within the circle depicting individual challenges, because local actors have to make decisions based on what they consider right for their ecosystem and what is legislated by local authorities.

\subsection{Telecoupling, Local Resilience, and Use Conflicts}

In the Mediterranean basin, humans have used forests for centuries, with variable outcomes, ranging from degradation to sustainable human cultural landscapes. In this issue, Moreno and colleagues [34] analyze the social-ecological trajectory in a marginal dryedge maritime pine forest in central Spain, an ecosystem highly vulnerable to desertification. These authors show that, despite recurring impacts of teleconnections (external climatic drivers) and telecouplings (wars, markets, major political changes, etc.), a century old management plan has provided resilience to the ecological and social components of the system, because forest function, including regeneration, and social needs were identified and well integrated by forest authorities. Hence, neglecting forest management in favor of more strict conservation policies could be, in some regions, counterproductive for community and ecosystem resilience.

Various contributing papers account for the impact of telecoupling that is represented in top-down policies, such as the European Union targets for greener energy [28], REDD+ programs [29], and carbon credits [26,27], highlighting the vertical dimension of conflict origin, as depicted in Figure 1. 


\section{Concluding Remarks: A Cautionary Tale on "Transitions"}

Currently, public policies are abound with all sorts of social transition objectives, and research is following with projects, publications, and journals devoted specifically to one or more transitions. As we briefly described above, forests are at the center of climate change adaptation and mitigation, with increased attention given today to new energy sources, such as wind farms or massive afforestation, for energy that will help an energetic transition [22]. However, these new land uses will necessarily imply new tradeoffs and challenges. Conflicts will continue to arise if the public and stakeholders observe multifunctional forests replaced by crop trees [35] in the name of an energy transition policy, making this strategy a clear source of considerable problems [36]. There are limits to the sustainability and resilience of forest ecosystems, and we need to carefully consider how to cope with these trade-offs, and which actions we undertake with our extant forests, as lagged responses may cause our mistakes to linger for generations to come [6].

Author Contributions: Conceptualization, J.F.F.-M., J.M. and M.A.Z.; writing-original draft preparation, J.F.F.-M.; writing—review and editing, J.F.F.-M., J.M. and M.A.Z. All authors have read and agreed to the published version of the manuscript.

Funding: J.F.F.-M. received support from a grant overseen by the French National Research Agency (ANR) as part of the "Investments d'Avenir" Programme (LabEx BASC; ANR-11-LABX-0034); M.A.Z was supported by grant DARE; RTI2018-096884-B-C32 (Ministerio de Ciencia e Innovación-MICINN, Spain).

Data Availability Statement: Not applicable.

Acknowledgments: The authors would like to thank the Editorial Office of Forests for their continuous support and invaluable help for achieving this Special Issue. We would also like to thank Lindy F. Lumsden for a thorough review of the final version of the manuscript.

Conflicts of Interest: The authors declare no conflict of interest.

\section{References}

1. Morford, S.; Parker, D.; Rogers, H.; Salituro, C.; Waldichuk, T. Culture, worldviews, communication styles, and conflict in forest management. J. Ecosyst. Manag. 2003, 3, 3-7.

2. Poynton, S.; Hurditch, W. Cooperation and conflict in forest management: Applying a theoretical model to the Australian problem. Aust. For. 1995, 58, 58-64. [CrossRef]

3. Pravat, P.S.; Humphreys, D. Using a multilevel approach to analyse the case of forest conflicts in the Terai, Nepal. For. Policy Econ. 2013, 33, 47-55. [CrossRef]

4. De Jong, W.; Ruiz, S.; Becker, M. Conflicts and communal forest management in northern Bolivia. For. Policy Econ. 2006, 8 , 447-457. [CrossRef]

5. Blicharska, M.; Angelstam, P.; Giessen, L.; Hilszczański, J.; Hermanowicz, E.; Holeksa, J.; Jacobsen, J.; Jaroszewicz, B.; Konczal, A.; Konieczny, A. Between biodiversity conservation and sustainable forest management-A multidisciplinary assessment of the emblematic Białowieża Forest case. Biol. Conserv. 2020, 248, 108614. [CrossRef]

6. Fernandez-Manjarres, J.F.; Tschanz, L. Assisted Colonization: Protect Managed Forests. Science 2010, 330, 1318. [CrossRef]

7. Byrnes, J.E.; Gamfeldt, L.; Isbell, F.; Lefcheck, J.S.; Griffin, J.N.; Hector, A.; Cardinale, B.J.; Hooper, D.U.; Dee, L.E.; Emmett Duffy, J. Investigating the relationship between biodiversity and ecosystem multifunctionality: Challenges and solutions. Methods Ecol. Evol. 2014, 5, 111-124. [CrossRef]

8. Mastrangelo, M.E.; Weyland, F.; Villarino, S.H.; Barral, M.P.; Nahuelhual, L.; Laterra, P. Concepts and methods for landscape multifunctionality and a unifying framework based on ecosystem services. Landsc. Ecol. 2014, 29, 345-358. [CrossRef]

9. Lu, N.; Liu, L.; Yu, D.; Fu, B. Navigating trade-offs in the social-ecological systems. Curr. Opin. Environ. Sustain. 2021, 48, 77-84. [CrossRef]

10. Borrass, L.; Kleinschmit, D.; Winkel, G. The "German model” of integrative multifunctional forest management-Analysing the emergence and political evolution of a forest management concept. For. Policy Econ. 2017, 77, 16-23. [CrossRef]

11. Bončina, A.; Simončič, T.; Rosset, C. Assessment of the concept of forest functions in Central European forestry. Environ. Sci. Policy 2019, 99, 123-135. [CrossRef]

12. Rai, A.; Singh, A.K.; Mehrotra, S.; Singh, N. Multifunctional tropical dry forests systems of India: Current need and future directions. In Innovation of Life Science Research; NOVA Publisher: Hauppauge, NY, USA, 2019; pp. 373-399.

13. Sardeshpande, M.; Shackleton, C. Wild edible fruits: A systematic review of an under-researched multifunctional NTFP (nontimber forest product). Forests 2019, 10, 467. [CrossRef] 
14. Grass, I.; Loos, J.; Baensch, S.; Batáry, P.; Librán-Embid, F.; Ficiciyan, A.; Klaus, F.; Riechers, M.; Rosa, J.; Tiede, J.; et al. Landsharing/-sparing connectivity landscapes for ecosystem services and biodiversity conservation. People Nat. 2019, 1, $262-272$. [CrossRef]

15. Perino, A.; Pereira, H.M.; Navarro, L.M.; Fernández, N.; Bullock, J.M.; Ceaușu, S.; Cortés-Avizanda, A.; van Klink, R.; Kuemmerle, T.; Lomba, A. Rewilding complex ecosystems. Science 2019, 364, 1328-1348. [CrossRef]

16. Van Meerbeek, K.; Muys, B.; Schowanek, S.D.; Svenning, J.-C. Reconciling conflicting paradigms of biodiversity conservation: Human intervention and rewilding. BioScience 2019, 69, 997-1007. [CrossRef]

17. Regan, H.M.; Colyvan, M.; Burgman, M.A. A taxonomy and treatment of uncertainty for ecology and conservation biology. Ecol. Appl. 2002, 12, 618-628. [CrossRef]

18. Hammond, J.S.; Keeney, R.L.; Raiffa, H. Smart Choices: A Practical Guide to Making Better Decisions; Harvard Business Review Press: Boston, Mass, USA, 2015; p. 243.

19. Hammond, J.S.; Keeney, R.L.; Raiffa, H. The hidden traps in decision making. Harv. Bus. Rev. 1998, 76, 47-58. [PubMed]

20. Kahneman, D.; Knetsch, J.L.; Thaler, R.H. Anomalies: The endowment effect, loss aversion, and status quo bias. J. Econ. Perspect. 1991, 5, 193-206. [CrossRef]

21. Heinrich, V.H.A.; Dalagnol, R.; Cassol, H.L.G.; Rosan, T.M.; de Almeida, C.T.; Silva Junior, C.H.L.; Campanharo, W.A.; House, J.I.; Sitch, S.; Hales, T.C.; et al. Large carbon sink potential of secondary forests in the Brazilian Amazon to mitigate climate change. Nat. Commun. 2021, 12, 1785. [CrossRef]

22. Luyssaert, S.; Schulze, E.-D.; Börner, A.; Knohl, A.; Hessenmöller, D.; Law, B.E.; Ciais, P.; Grace, J. Old-growth forests as global carbon sinks. Nature 2008, 455, 213-215. [CrossRef]

23. Gundersen, P.; Thybring, E.E.; Nord-Larsen, T.; Vesterdal, L.; Nadelhoffer, K.J.; Johannsen, V.K. Old-growth forest carbon sinks overestimated. Nature 2021, 591, E21-E23. [CrossRef]

24. Nik, V.M.; Perera, A. The Importance of Developing Climate-Resilient Pathways for Energy Transition and Climate Change Adaptation. One Earth 2020, 3, 423-424. [CrossRef]

25. Royer-Tardif, S.; Bauhus, J.; Doyon, F.; Nolet, P.; Thiffault, N.; Aubin, I. Revisiting the Functional Zoning Concept under Climate Change to Expand the Portfolio of Adaptation Options. Forests 2021, 12, 273. [CrossRef]

26. Akita, N.; Ohe, Y. Sustainable Forest Management Evaluation Using Carbon Credits: From Production to Environmental Forests. Forests 2021, 12, 1016. [CrossRef]

27. Fouqueray, T.; Génin, L.; Trommetter, M.; Frascaria-Lacoste, N. Efficient, Sustainable, and Multifunctional Carbon Offsetting to Boost Forest Management: A Comparative Case Study. Forests 2021, 12, 386. [CrossRef]

28. Sansilvestri, R.; Cordier, M.; Lescuyer, T. Winners and Losers in Energy Transition: Study Case of Wood Biomass Power-Plants Implementation in France. Forests 2021, 12, 1139. [CrossRef]

29. Alusiola, R.A.; Schilling, J.; Klär, P. REDD+ Conflict: Understanding the Pathways between Forest Projects and Social Conflict. Forests 2021, 12, 748. [CrossRef]

30. Schneider, J.; Ruda, A.; Blahová, M. Stakeholders' Perception of the Impact of the Declaration of New Protected Areas on the Development of the Regions Concerned, Case Study: Czech Republic. Forests 2021, 12, 580. [CrossRef]

31. Jackson, W.; Freeman, M.; Freeman, B.; Parry-Husbands, H. Reshaping forest management in Australia to provide nature-based solutions to global challenges. Aust. For. 2021, 84, 50-58. [CrossRef]

32. Branca, G.; Piredda, I.; Scotti, R.; Chessa, L.; Murgia, I.; Ganga, A.; Campus, S.F.; Lovreglio, R.; Guastini, E.; Schwarz, M.; et al. Forest Protection Unifies, Silviculture Divides: A Sociological Analysis of Local Stakeholders' Voices after Coppicing in the Marganai Forest (Sardinia, Italy). Forests 2020, 11, 708. [CrossRef]

33. Nugroho, K.; Carden, F.; Antlov, H. Local Knowledge Matters; Policy Press: Bristol, UK, 2018; p. 174.

34. Moreno-Fernández, D.; Zavala, M.A.; Madrigal-González, J.; Seijo, F. Resilience as a Moving Target: An Evaluation of Last Century Management Strategies in a Dry-Edge Maritime Pine Ecosystem. Forests 2021, 12, 1151. [CrossRef]

35. Manning, P.; Taylor, G.; Hanley, M. Bioenergy, food production and biodiversity-an unlikely alliance? Glob. Chang. Biol. Bioenergy 2014, 1-18. [CrossRef]

36. Sediri, S.; Trommetter, M.; Frascaria-Lacoste, N.; Fernandez-Manjarrés, J. Transformability as a Wicked Problem: A Cautionary Tale? Sustainability 2020, 12, 5895. [CrossRef] 